NOTE

\footnotetext{
1 Department of Biological Sciences, Towson University, Towson, MD 21252, USA

2 Insect Biocontrol Laboratory, Plant Sciences Institute, Agricultural Research Service, USDA, Beltsville, MD 20705, USA

3 Department of Biology, Georgia Southern University, Statesboro, GA 30460, USA

4 Vegetable Laboratory, Plant Sciences Institute, Agricultural Research Service, USDA, Beltsville, MD 20705, USA
}

\section{Serologic and genomic relatedness of group XIV spiroplasma isolates from a lampyrid beetle and tabanid flies: an ecologic paradox}

\author{
G. E. Gasparich, ${ }^{1}$ K. J. Hackett, ${ }^{2}$ F. E. French ${ }^{3}$ and R. F. Whitcomb ${ }^{4}$
}

Author for correspondence: G. E. Gasparich. Tel: +1 410830 4515. Fax: +1 4108302405.

e-mail: ggasparich@towson.edu

\begin{abstract}
Spiroplasma group XIV strain EC-1 ${ }^{\top}$ and other isolates from the lampyrid beetle Ellychnia corrusca form a serogroup with tabanid spiroplasma strains (TC-1 and TS-1). It was hypothesized that similarities among these strains reflect a transmission cycle in which lampyrid beetles serve as overwintering hosts and tabanid adults become infected and transmit a homogeneous population of spiroplasma strains during spring, summer and autumn. In the present study, variations in restriction fragment length patterns suggest the presence of multiple genovars. Genotypic analysis may therefore be a companion to serology in elucidating spiroplasma diversity, and may provide clues to strain host range.
\end{abstract}

Keywords: spiroplasmas, lampyrid beetles, tabanid flies
Spiroplasmas are classified in a group system $(9,12)$ prior to being assigned binomial names. Separation into distinct group designations is based on established criteria (16), including serological relatedness, PAGE patterns of proteins, utilization of glucose and arginine, and $\mathrm{G}+\mathrm{C}$ DNA base content. Determination of DNA-DNA homology, a standard criterion for separation of bacterial genospecies, is labour-intensive and poses technical difficulties. For that reason, DNA-DNA homologies have generally not been determined for spiroplasmas in which the first four tests are in agreement. Thus, because serologic evidence serves as the cornerstone of the spiroplasma classification scheme, designated groups are essentially serogroups (16). Because groups for which DNADNA homology data are available show very little intergroup relatedness, groups are generally considered to be putative species. Some species distinctions are more finely drawn than those among groups. Group I spiroplasmas, for example are divided into eight sub-groups (12), five of which have been given species status. The criteria for elevation of sub-groups to species have been defined by the International Committee on Systematic Bacteriology Subcommittee on the Taxonomy of Mollicutes (9). From a genetic standpoint, the most important criterion for species is a difference of at least $30 \%$ in DNA-DNA homology (i.e. less than $70 \%$ homology). More recently subgroups of groups XVI (1) and VIII (6), have been elevated to species. In all, the current spiroplasma inventory includes 18 named species, 10 unique but unnamed groups, and 14 sub-groups (12). Eight putative new groups have also been identified (18).

Problems in determination of the taxonomic boundaries of groups XVI and VIII illustrate pitfalls in reliance on serology to the exclusion of molecular genetic methodologies (e.g. DNA-DNA homology). Originally thought to be serologically distinct, group XVI strain CC- $1^{\mathrm{T}}$ and VIII strain EA- $1^{\mathrm{T}}$ were found to be related to other (putative) groups when 'bridge' strains (strains serologically cross-reacting with two or more groups) were discovered $(1,6)$. In both cases, DNA-DNA homology was needed to clarify relationships, resulting in the redefinition of each group as a 'supergroup' containing sub-groups (formerly separate groups).

The emergence of sub-groups as species challenges the concept that the group is taxonomically equivalent to the species. Those groups that represent strains with a narrow ecological niche [e.g. group II (strain DW-1 ${ }^{\mathrm{T}}$ ) or group XX $\left(\mathrm{LD}-1^{\mathrm{T}}\right)$ ] may indeed be equivalent to species. However, complex taxonomic relationships among strains within groups I, XVI and VIII, and undoubtedly others yet to be discovered, has resulted in a merging of groups, or creation of sub-groups. In these cases, it is the sub-group that represents the species. 
Table 1. Serological reaction of lampyrid and tabanid strains with EC-1 homologous antisera

\begin{tabular}{|lclc|}
\hline Strain/isolate & $\begin{array}{c}\text { Isolated } \\
\text { from: }\end{array}$ & Date and site of collection & Host \\
\hline Strain TS-1 & Gut & 2 September 1983; Newport News, VA & T. sulcifrons \\
Isolate 02033 & Blood & 26 July 1990; Beltsville, MD & T. sulcifrons \\
Isolate 02033 & Gut & 26 July 1990; Beltsville, MD & T. sulcifrons \\
Isolate TSG85 & Gut & 29 July 1985; Laurel, MD & 320-640 \\
Isolate 00153 & Gut & 18 July 1986; Beltsville, MD & T. sulcifrons \\
Isolate 00187 & Gut & 30 July 1986; Beltsville, MD & T. sulcifrons \\
Isolate 02026 & Gut & 19 July 1990; Beltsville, MD & T. sulcifrons \\
Isolate 02026 & Blood & 19 July 1990; Beltsville, MD & T. sulcifrons \\
Strain TC-1 92383 & Gut & 20 August 1983; Beltsville, MD & T. sulcifrons \\
Isolate EC-1A no. 5 & Gut & 6 April 1983; Beltsville, MD & T. calens \\
Strain EC-1 from EC-1A & Gut & 6 April 1983; Beltsville, MD & 320-640 \\
$\quad$ isolate EC-2 & & & E. corrusca \\
Isolate EC-1F & Gut & 6 April 1983; Beltsville, MD & E. corrusca \\
Isolate EC-5 group 1 no. 14 & Gut & 16 April 1983; Beltsville, MD & 2560 \\
Isolate EC-10 group 2 no. 27 & Gut & 18 April 1983; Beltsville, MD & E. corrusca \\
\hline
\end{tabular}

* Reacted at a DF titre of 1:10240 against antisera to strain TG-1, and is therefore a member of group XXIII.

Within groups or sub-groups, there is often substantial variation which may be related to the ecology of the organism (15). The current study was undertaken to determine if the inexpensive and easy-to-use method of RFLP analysis could be used to disclose variation of isolates within groups, e.g. variation suggested by diversity of ecological relationships of the hosts.

Group XIV strains were chosen for analysis; this group, like others, contains strains that are indistinguishable by serology. And, while this group includes strains isolated from insect species from phylogenetically diverse orders, those insects presumably interact trophically (7), providing opportunities for spiroplasma transmission. We hypothesize that the adults of one host, the lampyrid (firefly) beetle Ellychnia corrusca, contact adults of the other hosts, tabanid (horse flies and deer flies), at feeding sites, e.g. tree sap flows. This hypothesis has been supported by a recent study, in which laboratory transmission of spiroplasmas from infected $E$. corrusca adults to tabanid flies (Chrysops brimleyi and Hybomitra difficilis) was observed during cohabitation of the insects (13). These results, together with the presence of group XIV spiroplasma strains in adult $E$. corrusca fireflies that emerge from overwintering sites in early spring, followed by the appearance and increasing incidence of related strains in adult tabanids, suggest that group XIV spiroplasmas might overwinter in firefly adults and be transmitted to, and passed among, tabanid adults. Nevertheless, such evidence of adult-adult transmission in nature is circumstantial, and there is no evidence of larva-larva transmission. Although larvae of both hosts are predaceous in waterlogged soils, and may prey on one another, and larvae and pupae of other firefly species have been found to harbour non-group XIV spiroplasmas (8), cursory investigation of tabanid larvae has failed to yield isolates [Ellychnia larvae have not been so investigated, although other lampyrid larvae have been found to harbour spiroplasmas (8)].

In an attempt to determine whether RFLP analysis might provide clues to the transmission cycle of group XIV spiroplasmas, total chromosomal DNA from two E. corrusca strains and nine strains from tabanid flies was hybridized with a 16S rRNA probe. Results, which show a mixture of homology and non-homology, support the use of this technique for measuring intragroup variation among spiroplasma taxa.

\section{Origin of isolates}

Spiroplasmas were isolated (3) from E. corrusca (Coleoptera: Lampyridae) and a variety of tabanid flies $(3,4,5,17,18)$ from the insect gut and/or haemocoel.

\section{Culture media and growth conditions}

All strains were maintained in M1D medium (14) at $32{ }^{\circ} \mathrm{C}$. One-litre cultures for large scale chromosomal extractions were grown in BSR medium (9) at $32{ }^{\circ} \mathrm{C}$. Cultures were monitored by dark-field microscopy.

\section{Serological tests}

Spiroplasma deformation tests (19) were used to compare strains EC-1 ${ }^{\mathrm{T}}$, TS- 1 and TC- 1 , and isolates from Tabanus sulcifrons and E. corrusca using EC- $1^{\mathrm{T}}$ antisera. Results are shown in Table 1. With the exception of the blood isolate 02033 , which belongs to serogroup XXIII, all strains and isolates, from blood or gut, could be classified serologically as belonging to 


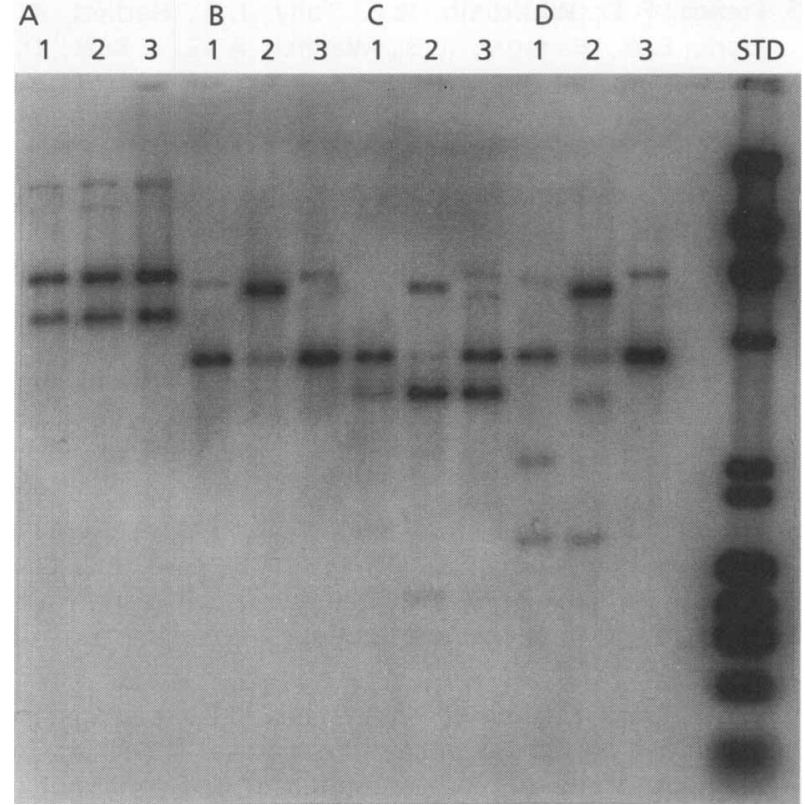

Fig. 1. RFLP patterns for group XIV strains and isolates. Numbers 1, 2 and 3 correspond to spiroplasma strains EC- $1^{\top}$ (EC1A no. 5), TC-1 (92383) and TS-1 (gut isolate from 2 September 1983), respectively. Letters $A-D$ indicate the following specific restriction endonuclease digestions: A, EcoRI; B, ECoRV; C, EcoRV and HindIII; D, EcoRV, Pstl and Xbal. STD indicates overlapping $\lambda / H$ ind III and $\phi \mathrm{RF} / \mathrm{Haelll}$ labelled DNA standards (sizes of the bands from largest to smallest are 23.1, 9.4, 6.6. 4.4, $2 \cdot 3,2 \cdot 0,1 \cdot 35,1 \cdot 08,0.87,0.60$ and $0.31 \mathrm{~kb}$ ).

one large, fairly diverse, group. Spiroplasma isolates from $T$. sulcifrons flies (TS-series isolates) ranged in titre from $1: 320$ to $1: 1280$, similar $(1: 640$ to $1: 1280)$ to procedural variation in strain TC-1 from Tabanus calens. Deformation titres from E. corrusca isolates from Beltsville, MD, exhibited a wider range of titres ( $1: 320$ to $1: 2560)$, overlapping those of group XIV spiroplasmas from tabanid flies.

\section{RFLP analysis}

Chromosomal DNA was extracted using the protocol of Carle et al. (2). RFLP analysis was performed by digesting $20 \mu \mathrm{l}$ aliquots of chromosomal DNA with restriction endonucleases EcoRI, EcoRV, HindIII, $X b a \mathrm{I}$ and $P s t \mathrm{I}$, under conditions recommended by the manufacturer. Digests were mixed with gel loading buffer and electrophoresed in $0.8 \%$ agarose (Seakem GTG, FMC) in $0.04 \mathrm{M}$ Tris-acetate and $1 \mu \mathrm{M}$ EDTA running buffer. To estimate the size of the RFLP hybridization bands, DNA size standards $\lambda /$ HindIII and $\phi$ X175/HaeIII were used. Following electrophoresis, DNA was blotted onto a nitrocellulose membrane by capillary transfer under alkaline conditions (11). The membrane was air-dried and then vacuum-dried at $80{ }^{\circ} \mathrm{C}$ for $60 \mathrm{~min}$. A $\left[{ }^{32} \mathrm{P}\right] \mathrm{dATP}$ labelled radioactive probe was produced by nicktranslation of $\mathrm{pR} 136$ [which contains a $4 \cdot 2 \mathrm{~kb}$ portion of Spiroplasma citri 16S rRNA DNA (10)].

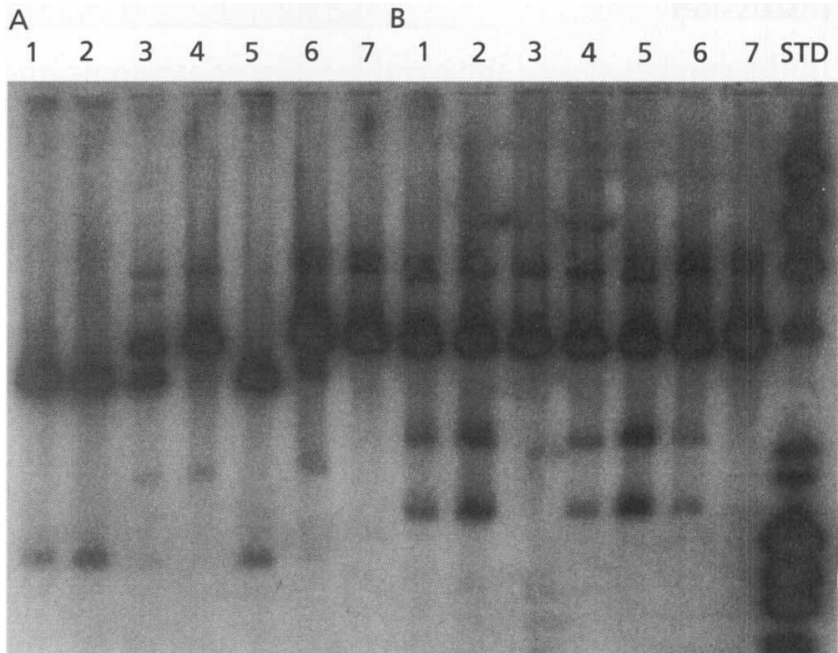

Fig. 2. RFLP patterns for group XIV strains and isolates. Numbers 1-7 correspond to spiroplasma strain TS-1 and isolates 02033G, TSG85, 00153G, 00187G, 02026G and 02026B, respectively. Restriction endonuclease digestion were with (A) EcoRV and HindIII, and (B) Xbal, Pstl and EcoRV. STD indicates overlapping $\lambda /$ HindIII and $\phi R F / H a e l l l$ labelled DNA standards (sizes of the bands from largest to smallest are 23.1, 9.4, 6.6. 4.4, $2 \cdot 3,2 \cdot 0,1 \cdot 35,1 \cdot 08,0.87$ and $0.60 \mathrm{~kb}$ ).

Hybridization was done under standard conditions (11) at $50^{\circ} \mathrm{C}$. Blots were washed twice with $2 \times$ SSC, $0.1 \%$ SDS for $10 \mathrm{~min}$ at $25^{\circ} \mathrm{C}$ to remove any unbound probe. Visualization of DNA fragments was achieved by autoradiography using Kodak XAR-5 film.

RFLP patterns for group XIV strains and isolates from $E$. corrusca, $T$. sulcifrons and $T$. calens were, in most cases, different. Although profiles from lampyrid strain EC-1 $1^{\mathrm{T}}$ (isolated 6 April 1983) and tabanid strains TC-1 (isolated 20 August 1983) and TS-1 (isolated 2 September 1983) from Beltsville, MD, were identical when digested with EcoRI (Fig. 1, set A), three other sets of digests showed either a difference in the intensity of specific bands (set B, EcoRV), a completely different RFLP pattern (set D, EcoRV, PstI and $X b a \mathrm{I}$ ), or altered combinations of intensity and banding patterns (set C, with EcoRV and HindIII). Nor were the profiles of the two E. corrusca isolates (EC-1 ${ }^{\mathrm{T}}$ and EC-27), collected on the same day from the same site in Beltsville, identical (data not shown). Five distinct patterns were discernable for the seven serologically related $T$. sulcifrons gut isolates restricted with endonucleases EcoRV/HindIII (Fig. 2, lanes A1-7) and $X b a \mathrm{I} / P s t \mathrm{I} / E c o \mathrm{RV}$ (lanes B1-7): strain TS-1 and isolates $02033 \mathrm{G}$ and $00187 \mathrm{G}$ were in one group, isolates $00153 \mathrm{G}$ and $02026 \mathrm{G}$ were in another group, and strain TSG85 and isolates $00187 \mathrm{G}$ and $02026 \mathrm{~B}$ were in separate groups. Interestingly, of the two $T$. sulcifrons specimens from which gut and blood samples were obtained, one (02033) had different spiroplasma groups (XIV and XXIII) in the gut and blood, and the other (02026) had group XIV spiroplasmas with different restriction profiles. 


\section{Discussion}

In the current study, the combination of serologic and RFLP analyses revealed relationships that either technique, alone, did not. Serology showed the close taxonomic relationship of lampyrid and tabanid isolates, despite their divergent insect hosts, facilitating their quick and easy identification to group. Because the observed variation was continuous, the isolates must be considered to represent a single serovar. RFLP analysis, by contrast, when performed on representative isolates from the different hosts, revealed the possible existence of genovars within the serovar. The replicability of RFLP profiles therefore allowed a finer differentiation than was possible using the serological method alone and offers an approach to the study of intragroup variation in mollicutes. A suggested approach, for example, might be to determine the existence of genovars by RFLP, followed by more labour-intensive genomic analyses (e.g. DNA sequencing could be performed on representative genovars).

The combined use of serological and molecular tools also showed potential for revealing ecological relationships. In the current case, some group XIV strains were indistinguishable serologically, yet were isolated from divergent insect taxa, i.e. lampyrid beetles and tabanid flies, for which no proof of an ecological link is known. This created an ecological paradox. In this case, RFLP analysis and other DNA fingerprinting methods will need to be employed in the study of additional strains to fully reject or support the serological-based hypothesis that spiroplasmas were being transmitted among these evolutionarily divergent insect hosts.

For taxonomic purposes, the current results suggest that it would be appropriate to use RFLP analysis to re-examine spiroplasma strains previously identified by serology. Such investigations, when considered collectively, might also eventually lead to a hypothesis as to whether the serovar or the genovar is the appropriate unit for establishing mollicute taxonomies or for the determination of ecological relationships. At present, both methods appear to have value.

\section{References}

1. Abalain-Colloc, M.-L., Williamson, D. L., Carle, P., Abalain, J. H., Bonnet, F., Tully, J. G., Konai, M., Whitcomb, R. F., Bové, J. M. \& Chastel, C. (1993). Division of group XVI spiroplasmas into subgroups. Int J Syst Bacteriol 43, 342-346.

2. Carle, P., Saillard, C. \& Bové, J. M. (1983). DNA extraction and purification. Methods Mycoplasmol 1, 295-299.

3. Clark, T. B. (1984). Diversity of spiroplasma host-parasite relationships. Isr J Med Sci 20, 995-997.

4. Clark, T. B., Peterson, R. V., Whitcomb, R. F., Henegar, R. B., Hackett, K. J. \& Tully, J. G. (1984). Spiroplasmas in the Tabanidae. Isr J Med Sci 20, 1002-1005.
5. French, F. E., Whitcomb, R. F., Tully, J. G., Hackett, K. J., Clark, E. A., Henegar, R. B., Wagner, A. G. \& Rose, D. L. (1990). Tabanid spiroplasmas of the southeast USA: new groups and correlation with host life history strategy. Zentralbl Bakteriol Suppl 20, 919-921.

6. Gasparich, G. E., Saillard, C., Clark, E. A., Konai, M., French, F. E., Tully, J. G., Hackett, K. J. \& Whitcomb, R. F. (1993). Serologic and genomic relatedness of group VIII and group XVII spiroplasmas and subdivision of spiroplasma group VIII into subgroups. Int $J$ Syst Bacteriol 43, 338-341.

7. Hackett, K. J. \& Clark, T. B. (1989). The ecology of spiroplasmas. In The Mycoplasmas, vol. V, pp. 113-200. Edited by R. F. Whitcomb \& J. G. Tully. New York: Academic Press.

8. Hackett, K. J., Whitcomb, R. F., Tully, J. G., Lloyd, J. E., Anderson, J. J., Clark, T. B., Henegar, R. B., Rose, D. L., Clark, E. A. \& Vaughn, J. L. (1992). Lampyridae (Coleoptera): a plethora of mollicute associations. Microbiol Ecol 23, 181-193.

9. International Committee on Systematic Bacteriology Subcommittee on the Taxonomy of Mollicutes (1995). Revised minimum standards for description of new species of the class Mollicutes (Division Tenericutes). Int J Syst Bacteriol 45, 605-612.

10. Laigret, F., Grau, O. \& Bové, J. M. (1990). Comparison of $16 \mathrm{~s}$ rDNA sequences of various mollicutes. Zentralbl Bakteriol Suppl 20, 435-440.

11. Sambrook, J., Fritsch, E. F. \& Maniatis, T. (1989). Molecular Cloning: a Laboratory Manual, 2nd edn. Cold Spring Harbor, NY: Cold Spring Harbor Laboratory.

12. Tully, J. G., Rose, D. L., Clark, E., Carle, P., Bové, J. M., Henegar, R. B., Whitcomb, R. F., Colflesh, D. E. \& Williamson, D. L. (1987). Revised group classification of the genus Spiroplasma (class Mollicutes), with proposed new groups XII to XXIII. Int J Syst Bacteriol 37, 357-364.

13. Wedincamp, J., French, F. E., Whitcomb, R. F. \& Henegar, R. B. (1996). Spiroplasmas and entomoplasmas associated with tabanids (Diptera: Tabanidae) and fireflies (Coleoptera: Lampyridae). J Invertebr Pathol 68, 183-186.

14. Whitcomb, R. F. (1983). Culture media for spiroplasmas. Methods Mycoplasmol 1, 147-158.

15. Whitcomb, R. F. (1994). Species concept in eukaryotes and prokaryotes: search for a synthesis. IOM Lett 3, 1-7.

16. Whitcomb, R. F., Bové, J. M., Chen, T. A., Tully, J. G. \& Williamson, D. L. (1987). Proposed criteria for an interim serogroup classification for members of the genus Spiroplasma (class Mollicutes). Int J Syst Bacteriol 37, 82-84.

17. Whitcomb, R. F., Hackett, K. J., Tully, J. G., Clark, E. A., French, F. E., Henegar, R. B., Rose, D. L. \& Wagner, A. G. (1990). Tabanid spiroplasmas as a model for mollicute biogeography. Zentralbl Bakteriol Suppl 20, 931-933.

18. Whitcomb, R. F., French, F. E., Tully, J. G., Gasparich, G. E., Bové, J. M., Carle, P., Clark, E. A. \& Henegar, R. B. (1992). Tabanid spiroplasma serovars. IOM Lett 2, 115.

19. Williamson, D. L., Tully, J. G. \& Whitcomb, R. F. (1979). Serological relationships of spiroplasmas as shown by combined deformation and metabolism inhibition tests. Int J Syst Bacteriol 29, 345-351. 